\title{
Tourism and Rural Heritage: A Win-Win Relation? The Conditions of Heritage Making in Touristic Rural Regions
}

\author{
Alain Bourdin ${ }^{\mathrm{a} *}$, Tingting Wan ${ }^{\mathrm{b}}$ and Philippe Delbos ${ }^{\mathrm{c}}$ \\ a Lab'urba, École d'urbanisme de Paris, Université de Paris-Est, Paris, France \\ $b$ LAVUE/CNRS, Université Paris Nanterre, Paris, France \\ c Heritage Architect, Toulouse, France. \\ *Corresponding author: bourdin@msh-paris.fr
}

\begin{abstract}
The relationship between heritage and rural development takes place within the heritage making process. It presents different characteristics of what exists in urban context, especially through the role that can play the built heritage in the reception of the tourists. The study of the case of a French department, the Gers, characterised by an important intangible heritage linked to gastronomy and agriculture, but away from the major flows of mass tourism, reveals three major criteria for success: the importance of organising an actor's network that gathers the world of local economy, tourism and heritage, in conjunction with local authorities; the existence of a strong legitimation structure that justifies these links. In France it was developed from a scientific approach: that of rural ethnology; the inscription in a temporality which allows successive stages and which is as much that of the local development project as that of the patrimonial action itself.
\end{abstract}

KEYWORDS heritagisation, rural heritage, local development, intangible heritage, cooperation, heritage legitimation, owners

Received April 12, 2019; accepted June 17, 2019.

\section{Introduction}

The call for articles says: 'Preservation is the basis and premise of revitalisation: the latter is the guarantee and ultimate purpose of the former. This formula highlights the primacy of revitalisation. However, it seems to imply a sequential division, starting with the identification of the heritage, continuing with the safeguarding and ending with revitalisation. This type of division easily worked on urban monuments, which were well known and which had to be preserved for their own value; then we saw the concern of revitalisation intervening more and more early.

Today, particularly in the case of the minor rural heritage, there is (in many countries) a different situation. The three stages take place at the same time and are totally linked. This is typical of a process of making heritage (heritagisation), as it has been much described in recent decades. In most cases, we cannot hope to mobilise resources for the sole preservation of a minor rural heritage: it must prove its usefulness. The satisfaction of the inhabitants-if it exists-is certainly important but rarely enough. On the other hand, the contribution to the tourist economy usually seems the best way to justify any kind of action on built heritage, it is thus the 'engine' of the making of heritage.

It is this process that we want to question, in the particular context of a rural world that has important heritage resources, a real attractiveness and a certain social dynamism, but which nevertheless lies outside dominant circuits of heritagisation, those directly led by the states (Heinich 2009).

This questioning seems relevant to us considering the characteristics of the abundant literature on heritagisation, at least with regard to the built heritage. It essentially presents case studies and a few rare theoretical texts, and produces two main types of conclusions: on the one hand, an insistence on the importance of the adhesion of the population; some famous examples, such as that of Wadden Sea (Groote 2005), are studied 
to show how a deficiency in this area can lead to the refusal of the UNESCO listing. On the other hand, this literature refers to a theoretical set organised around the critique of the globalisation of culture, the transformation of heritage and authenticity into objects of consumption, its staging, etc. (e.g. Frigolé [2010] Poria and Ashworth [2009] Zukin [2010] and many authors who are inspired by D. Harvey). Those who theorise from a different perspective (Bendix 2008), remain rare. Whatever their interest, these theories are very general and we can always 'stick' them on specific situations, but it does not really account for the process itself. There is a weakness of 'middle-range theory" ${ }^{1}$ that does not seek universal explanation (e.g. neo-liberalism) but want to provide a framework to gather and compare a set of particular situations without erasing their specificities ${ }^{2}$. It is at this level of theoretical elaboration that we want to situate ourselves.

Insofar as the process of making heritage constitutes a set of actions, it seems legitimate to question it on the basis of classical axes of the analysis of the action. We will privilege three: the modes of involvement and coordination of the actors ${ }^{3}$, what legitimises the action ${ }^{4}$, and the temporalities of the action-a theme that is too often left to the historians.

For that purpose, we rely on a case. But our approach is not monographic. This case has been chosen for its exemplary value, and, above all, because it makes it possible to develop a questioning, in an inductive approach ${ }^{5}$, where the rise in generality is controlled by the report to the specificity of the case. In the first part we will present the situation studied, the method used to study it, its context, its different stages, the institutional mechanisms and procedures. Then we will analyse the characteristics of the collaboration between actors, we will highlight the structures of legitimacy by insisting on the French specificities of the notion of rural heritage, and we will question the temporalities of the process. We will draw from it a set of propositions for the theory and practice of heritagisation.

\section{The Choice of an Example}

According to DATAR (2003), there are three types of rural areas in France: (1) the new urban countryside whose inhabitants work mainly in the city; (2) the fragile countryside which empty their population; and (3) the countryside in search of a new economic equilibrium. These last ones usually give a strategic place to tourism. The department ${ }^{6}$ of Gers includes these three types of countryside, but mainly the first and the third. Tourism is therefore an important resource, especially as the elements that can attract tourists are also suitable for residents linked to the city.

But all studies on tourism show that the rural areas that benefit from this economic activity are located either at the seaside or in the high mountains, or in the immediate vicinity of a large 'attractor', for example an international reputation site. The Gers does not have this type of wealth: it is therefore necessary to create value that can attract visitors, the process being of the same nature as when Dubai creates huge malls to attract tourists. For them, the best way to create value is to develop heritage, while there is already rich heritage, including the intangible. The latter, in this department, is essentially agricultural, with 18 food labels: six for wines, 10 for animal products and two for plants. Many of its products (especially Armagnac) are a worldwide success.

The department benefits from a network of small historic towns, all of which have real heritage value. Among them, there are 34 'bastides' (out of the 260 listed in France). 308 buildings are protected (2011 figures, source Ministry of Culture), including 81 at the first level (classified historical monuments) and 227 in the second (listed in the supplementary inventory). $38 \%$ are religious buildings (churches and convents), $27.8 \%$ castles, $23.8 \%$ other objects (mainly dovecotes, halls, remains of fortifications, bridges and Roman remains) and 10\% houses. In addition, there is a very dynamic network of old spa cities, part of which is in this department.

Its specific situation makes it a rather typical department in the South of France, away from tourist flows linked to large attractors and strongly marked by the presence of numerous second homes, with a significant proportion of foreign occupants (Table 1). In addition, in this context, local development initiatives are totally endogenous, even if they rely on external aid. This is true for the heritagisation of the rural habitat, which is in synergy with the strategy of the attracting event (notably the Jazz in Marciac festival). Everything converges to illustrate a 'soft', endogenous and quasi-consensual making of heritage, at least during the studied period (1990-2012).

This is not the only possible example in France. If we chose this one precisely, it is because of an opportunity: the third author of this article worked about 15 years during the studied period as architect consultant with the $\mathrm{CAUE}^{10}$ of Gers. He has access to the archives and therefore to all the files that were submitted for grants. The other two authors questioned him for a long time 
Table 1 Data on tourist activity in the Gers in 2018 (Source: Departmental Committee of Tourism).

\begin{tabular}{|l|c|}
\hline Second homes total & 9,160 \\
\hline Second homes owned by foreigners & 1,650 \\
\hline Number of beds offered by hotels 2018 & 2,439 \\
\hline $\begin{array}{l}\text { Number of beds offered by B\&B, country } \\
\text { cottages and other private accommoda- } \\
\text { tions }\end{array}$ & 9,125 \\
\hline Number of visitors per year (2017) & 1.7 million \\
\hline
\end{tabular}

and he asked for additional information from the tourism services. We also consulted the documentation available online. However, this is not a monograph but a case study intended to feed a reflection on the process of making heritage in rural areas.

\section{The Three Stages of Making Rural Heritage in the Gers}

The heritage process described here begins after the decentralisation of the French state in the late 1980s. The regions are seeing their responsibilities increase in terms of local development, the departments are then powerful communities and Europe is feeding a Regional Development Fund (ERDF) that subsidises projects for territories with economic levels below the European average. In the Gers, it is the farming community that takes the initiative, mainly to promote the high-end products of agriculture and ensure the attractiveness of the territory.

\section{Step 1: Valorising the Agricultural Heritage}

During a first period of about 10 years (1990-2000) the actions carried out (advices, information, financial incentives) target the farmers, owners of premises having a patrimonial value and which can be transformed to welcome tourists. The hotel supply is then very low and the decision makers favour the reception at the private individuals in 'country cottages'. This qualification corresponds to a label obtained by joining one of the two 'gites de France' or 'Clévacances' associations, both of which are composed of participating owners. They are subject to fairly strict standards on the facilities and characteristics of the reception. This goes hand in hand with the promotion of local products, provided for a part by the owners of these places $^{8}$. Economically, even when financial aid is limited, the profitability is fairly easy to find, in addition to an agricultural activity.

\section{Step 2: 'Tourism of Character' and Development of the Hotel Industry}

After 10 years, the stock of local agricultural and especially farmers likely to be interested in this type of project is almost exhausted. A reorientation is necessary. It takes the form of an insistence on 'tourism of character', therefore the search for a 'high-range' clientele. New actors 'project holders' are solicited. They are also recruited among quite a few newcomers (French or not) who wish to create an economic activity related to their residence. More specifically, new actors are often young retirees with relatively comfortable incomes, who have sold their urban residences, especially in Paris or London, and who have significant capital to invest in real estate.

They can therefore finance the quite expensive cost of the real estate rehabilitation projects. These projects include for example their own residence and two or three rooms or accommodations for tourists ${ }^{9}$, and most often, offer many elements of comfort and pleasure, in the housings themselves and around (swimming pool, terrace etc.), and a real aesthetic quality that applies to buildings and their surroundings. However, the traditional functions are rarely respected, because most of the time, the project changes completely the original use (of the agricultural building, mill, barn etc. to housing). These new investors are mainly interested in buildings of particular interest, such as water mills, which allows the preservation of quality patrimony objects and the detection of properties, most of which (wash houses, pigeon houses, mills) are not included in inventories or classifications.

The relay is then taken by the traditional circuit of heritage, in particular that of the administration of the State. Here again, after about less than a decade, the vein begins to run out, especially because the new pensioners mentioned above discover that the hotel industry is a real profession, even on the scale of a very small structure of reception, that the tourist season is short and that to find customers in the rest of the year must know how to do it. This doesn't cause a collapse, but a partial renewal of this population, with the arrival of owners who have taken the measure of the constraints of the reception, who know how to use the internet and social networks and invent services or events, related or no to intangible heritage.

At the same time, another category of heritage and touristic properties develop: lodging (gîtes d'étape). The pilgrimage to St. Jacques de Compostela, which was a major pilgrimage of Christianity during a whole part of the Middle Ages, has found a new success, and every year 
hundreds of thousands of people take their old paths, on all or part of the itinerary, for religious reasons or for the pleasure of hiking. A part of them (especially the most religious) frequent the inexpensive and very simple accommodation: the lodging. Two of the main roads of St. Jacques cross the Gers. This has made it possible to restore farm buildings, in a much simpler, less expensive, and often much more respectful way towards the traditional distribution of space. But the logic of touristic development has led to other projects. The department of Gers had an old hotel structure that did not adapt to both the standards and current expectations. However, especially with the development of events, in particular summer festivals, the 'homestay' (chez l'habitant) welcome could not suffice the need. A new phase, largely subsidised by the region and Europe, has focused on the creation of hotels in existing buildings. This has led to the restoration of hotel establishments, sometimes very old, or the development of relatively large buildings, which had other functions (for example, schools, public buildings). A new component was added to the restoration of the rural heritage, although this was not the main goal.

This new approach (centred on hotels with 15 to 30 rooms) did not lead to the presence of large hotelier groups. It was done with small investors, often belonging to the category of newcomers mentioned above, but with a stronger economic project.

\section{Step 3: Towards Mass Tourism}

Simultaneously to the end of subsidies from the Department in 2012, and from the Regional Government and Europe in 2017, a new procedure appears, which is characteristic of a third step: the creation in 2008 of the regional label of 'major sites', which was given to three territories in the Gers: Auch, Marciac (with its festival) and Grand Ar$\operatorname{magnac}^{10}$. Even if the development of the heritage remains an important concern, the funding that this label entails is primarily intended to accommodate a greater number of tourists in already known regions, in particular for the value of their tangible or intangible heritage, and to facilitate the creation of circuits to accommodate the tour operators' buses.

\section{How to Help Homeowners}

The aid system applied to the various works is very complicated and varies according to the different stages mentioned, but its basic principles do not vary much. They can be summarised as follows: a. They address on a voluntary basis private owners or municipalities owning real estate.

b. The higher the requirements for owners, the higher the aid can be, up to about half the cost of the work. These requirements may concern the building itself or its tourist operation. The value of heritage dimension is a high constraint that can lead to significant aid. The hotel industry must also respect a set of strong constraints (accessibility of all the rooms for disabled persons etc.) that justify important aids.

c. Respect of building exigencies is subject to verification by the organisations that approved the project and the government services. Sanctions can be applied if they are not properly respected, but this is a rare situation.

d. The requirements concerning the tourist exploitation (except in the form of hotel) are that the commitment in the network (Gites of France or Clévacances) must last at least five years and that tourist use must last 10 years. If there is a sale before the completion of these deadlines, the seller must refund the amounts received in proportion to the years actually accrued, even if the activity continues. This is more common and actually implemented at the time of sale.

e. It is possible to subsidise the whole project or to award aid which concerns only one aspect, for example energy saving. There are specialised organisations that attribute such aid and take little interest in the overall project. But as many subsidies are cumulative, skilled architects in the administration can add-on significant help on the same project.

f. There are two forms of assistance: the subsidy and the tax exemption (often capped ${ }^{11}$ ), which can take different forms. Some exemptions are only available to a specific category, including farmers with regard to tourism exploitation.

g. Finally, when asking for European funding, the procedure requires the projects to be examined and classified by a commission.

These principles, other than reserving certain benefits for a single social or professional category, are those found in many other construction or rehabilitation contexts ${ }^{12}$.

\section{What the Process Produces}

What are the direct effects of these different actions on local development? It must first be noted that the economic dimension is poorly known. Indeed, there are no microeconomic studies to evaluate the particular impact of a specific action. Only the evolution of the entire economic sector, in this case tourism, is considered. In this regard, the 

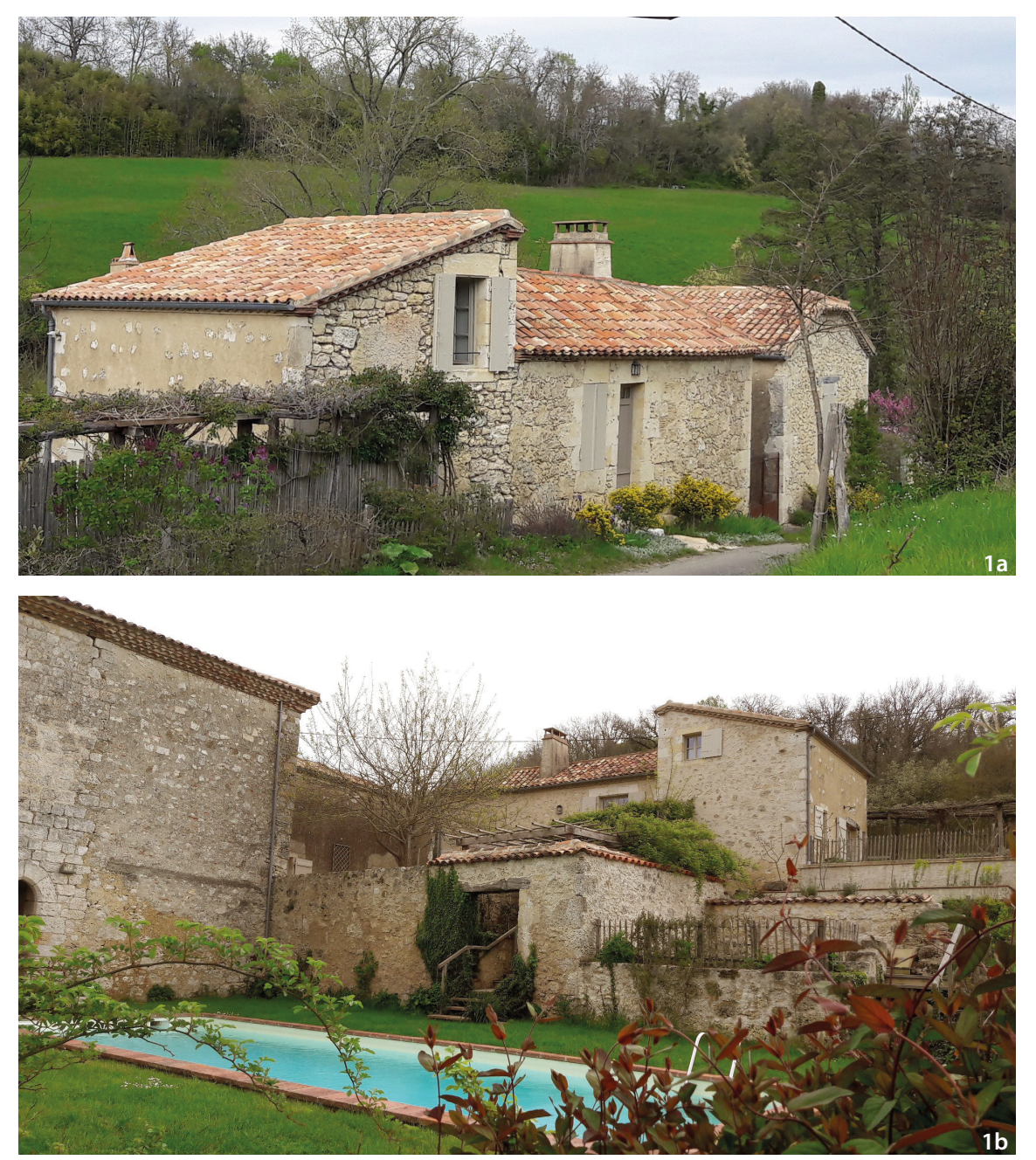

Figure 1 The old mill (Source: the author).

official reports conclude that tourism indicators are regularly increasing over the period under consideration. This is essentially reflected by the increase in the number of nights registered in different types of accommodation. The documents consulted ${ }^{13}$ show that in Gers the sector is progressing steadily, but rather weakly, unlike what happens in the seaside or high mountains regions, where monuments or attractors are able to gather many international customers.

With regard to the housing stock, the available information $^{14}$ shows that although its growth ceases in many parts of France after 1990, it's not the case in the Gers, where it continues to increase slowly, as well as the number of foreign owners, rather more than in most other departments in the region. Overall, according to the experts (after consulting websites specialised in real estate and articles devoted to the real estate in the regional daily newspaper the Dépèche $d u$ Midi) the market was held steady for a large part of the period, with a peak of price in 2003 without significant speculative effect, and today the market is rather fragile. It would be very risky to put the market condition in relation with the decline in aid starting in 2012, or the ERDF (Europe) and the region stop funding in 2017, as it is risky to attribute a speculative effect to their existence.

So the question arises as to what are the heritage outcomes of this process. Three examples illustrate the different facets of this heritage, reinvented or invented.

The first one (Figure 1a, Figure 1b) concerns an isolated house (an old mill), quite close to Lectoure, a small city remarkably in terms of heritage, in which the owners, who have just refocused their agricultural activity on market gardening, want to create four B \& B rooms that will bring them a secondary activity in addition to their own housing. They also plan to create a pool, a vegetable garden and amenity, and restore a small bridge over the stream that fed the mill. A very precise plan for the layout of the surroundings is drawn up. The evaluators are also concerned with the restoration of the traditional elements of the mill.

The second (Figure 2) illustrates the development of upmarket hotels in heritage places. As the project is new, environmental and access concerns for people with 


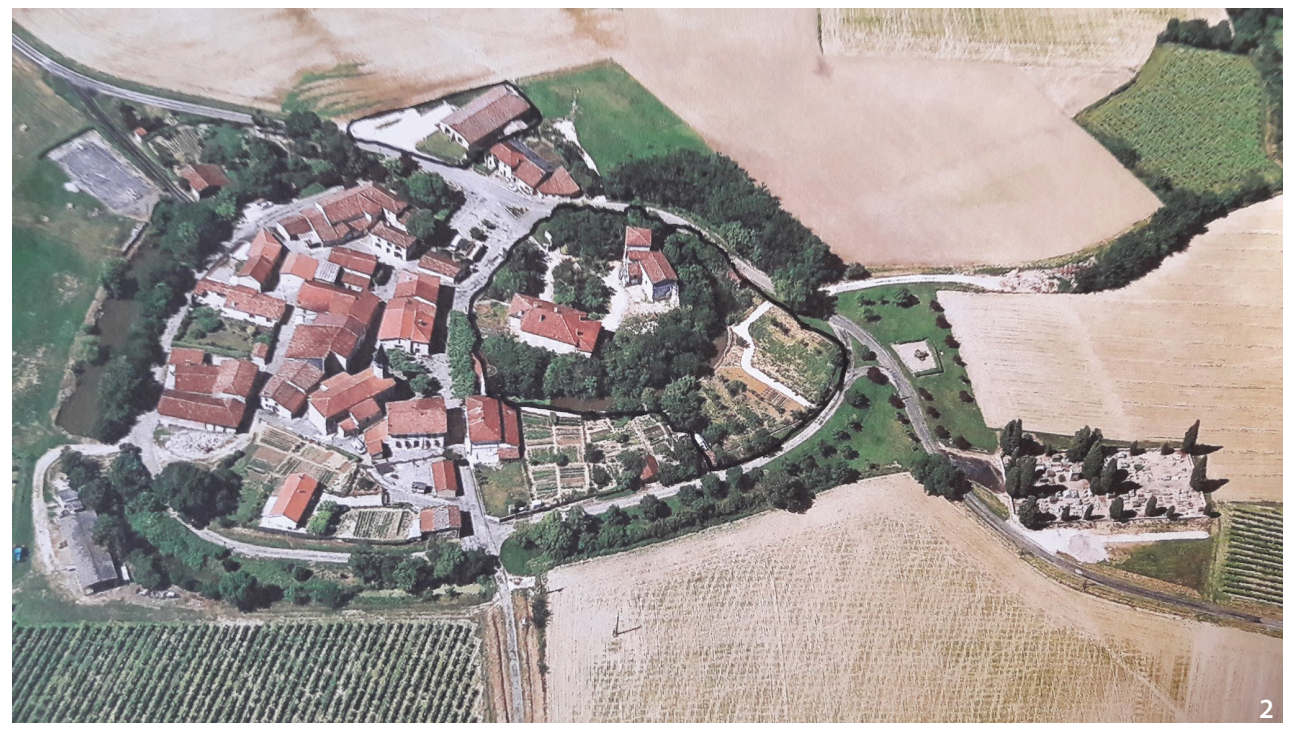

Figure 2 Centre village of the high-range hotel (Source: CAUE of Gers). disabilities are much more diverse and demanding, in line with legislative developments. As the picture shows, the project is located in a very small village that occupies the space of a medieval castle. The road to Santiago de Compostela is nearby and the mayor wants to attract pilgrims. This region is also the one that produces the best Armagnac. A pleasure park surrounded by ditches and associated with a wine marketing activity accompanies the building concerned. Before being subsidised, this 'upscale' hotel was submitted to analyse of its carbon footprint. It also had to present guarantees concerning water management through saving devices, and compliance, including training for staff, to the requirements of the 'tourism and disability' label.

The third is in the same village and has two components: on one side one building that can accommodate pilgrims or hikers in rooms of four people with the necessary sanitary facilities. On the other, the transformation of a concrete water tower, built in 1932-1933, into a 'micro cottage' for two people (Figure 3a, Figure 3b). Several levels, accessed by a micro lift or an external staircase, were built in the water tower. A local artist, J-P Chambas, has dressed the water tower with a fresco that evokes certain elements of regional heritage.

This example illustrates the desire to have a diversified offer in the same village, the interest for the modern heritage represented by the water tower; the call for contemporary art in the heritage through the fresco; and the possible role of the mayor representing the municipality.

From the information we had access to, we can advance a diagnosis without great risk to be mistaken: the actions of the rehabilitation of the rural real estate have not been an economic locomotive in the sector of the housing or even in that of the tourism, but they have helped to maintain a position: the Gers has slightly progressed. They have especially helped to clarify an image and to reinforce its coherence: the Gers carrying a rich intangible heritage of food and health with its tradition of spa towns, with its related architectural heritage and landscape. The action taken can hardly be judged by its direct importance to the housing market, which is quite low, or even by its economic development, but rather by the role played by the heritage making process itself as a common project, a cement of cooperation between actors and place where the dynamism of a generation is expressed.

\section{Coordination, an Essential Factor}

Coordination is the first dimension we wanted to explore. In France and in many countries, the action concerning heritage falls into a specialised and autonomous sector. There are specific administrations, legislation, special procedures, specialised professionals (especially architects) and experts, etc. This forms a relatively closed system. The relationship between this system and the actors, whether owners or local authorities, appears usually as two different worlds through a principle of reciprocal externality, and the problems of coordination and cooperation arise first inside the field of heritage.

Such is not the situation in the case studied. Though the specialised field of heritage well exists, it is overshadowed by a larger system: that of the local rural development. As a result, cooperation involving many more actors must rely on something other than the sharing of common knowledge, the interest in heritage values only, or the implementation of specialised regulations (grading, etc.). 


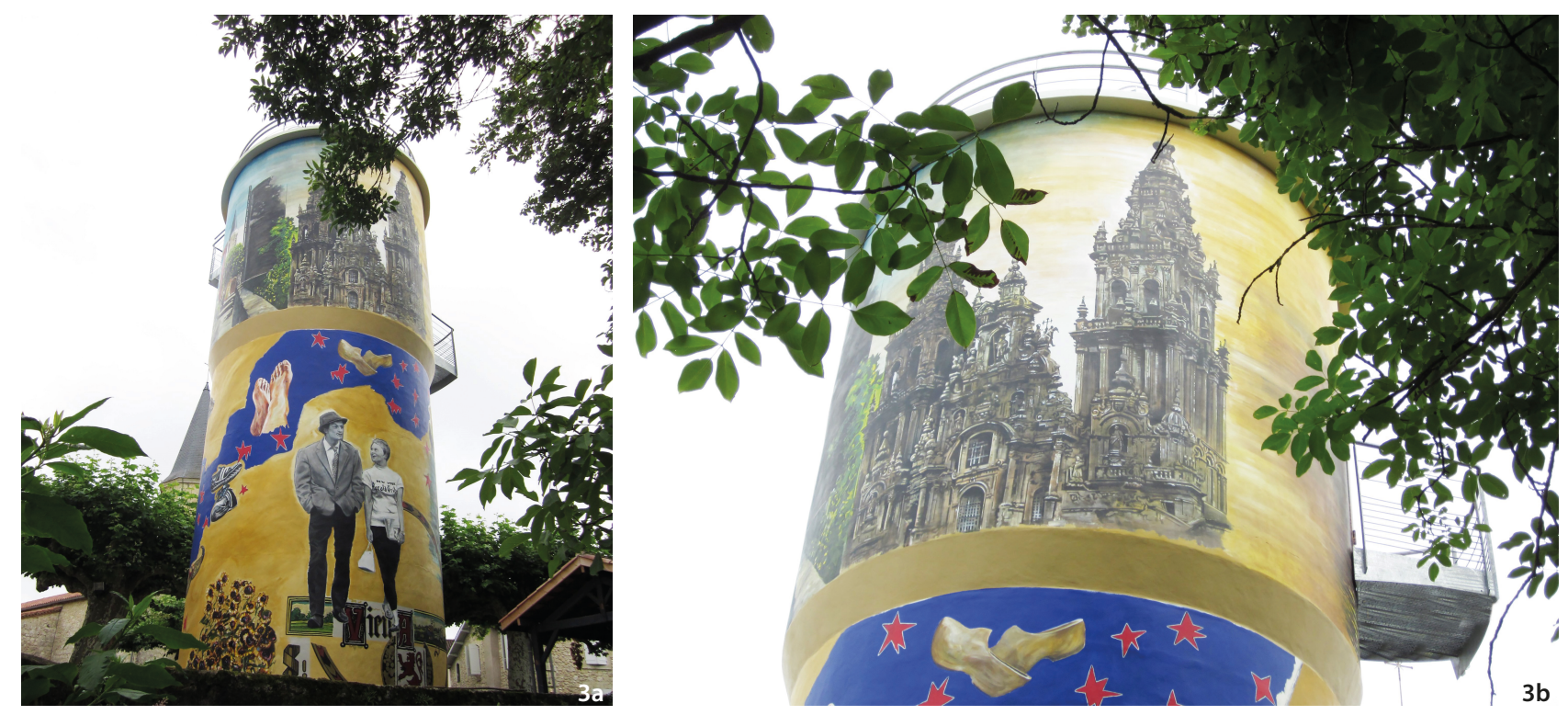

Figure 3 Water tower after the rehabilitation (Source: the author).

In this case, the actors involved belong to several categories, which need to be clearly defined:

a. The State and the different organisations that depend on it. Essentially, the heritage administration that is responsible for enforcing legislation and preserving the major heritage intervenes mainly in urban projects. The management of tourism, even though it depends mainly on local authorities, is linked to the state, particularly through the administration of the Ministry of Tourism.

b. Local authorities. The Region is the privileged interlocutor of the European institutions, through the ERDF (European Regional Economic Development Fund), which provides financial support for the achievements described. The Department is a major player in the field of tourism. It should be remembered that the Department has no subordinate relationship with the Region (only with the State): theoretically, they have different tasks, and when competencies overlap, they have to find the agreements. Here both local authorities are involved in tourism and local development, although each has a specific role. They must therefore cooperate or at least coordinate. The third level of local authorities, the municipalities, does not intervene to finance the project, but it authorises the work and especially it can promote a project vis-à-vis other actors.

c. Professional networks. These are partly very old organisations, defined by law, which are part of the State institutions and benefit from legally established funding and capacity for action, but which have a very strong autonomy vis-à-vis the political authorities. Mainly these are the chambers of agriculture, the chambers of commerce and industry, the chambers of crafts (which gather the craftsmen). All are usually present in the described procedure. On the other hand, there are less institutional networks that are acknowledged and helped by the public authorities. This is the case of the tourist reception networks mentioned above: although they are associations composed of owners who rent their property, they are also holders of labels, which they attribute and control. In the case studied, pre-accession to one of these networks is compulsory to obtain a subsidy. Today their direct competitor is the Airbnb platform, against which they struggle by reorganising themselves. But this new actor-which is an intangible actor-disrupts the relationship system considerably. We will also mention associations of architects or landscapers or those of professionals in the food and hotel sector (Armagnac, gastronomy, etc.).

d. The 'intermediaries'. These are mainly two organisations that depend on the department but remain private actors with a certain autonomy: on the one hand, the CAUE (see Note 9) which brings together architects and landscapers and intervenes to advise municipalities and individuals on their development projects or construction. Their role is to intervene before the decision-making and to prepare it, while the State and communities administrations are involved in the decision itself. They work in permanent collaboration with the professional networks and with the second major intermediary, which is the Departmental Committee of Tourism (CDT), which brings together the actors of 
tourism, mainly to coordinate them in the implementation of the tourist policies.

e. The owners. There are several categories:

Farmers for whom the essential is to sustain their activity in adapting them to new conditions. They are highly integrated with agricultural and sometimes tourist networks. Resale only becomes their goal if they are no longer in physical or psychological condition to continue their activity and they have no family members to take over.

Newcomers. This group includes young retirees who already had a connection to the territory (for example they had a second home) and who came to settle permanently. They have the reactions quite similar to those of farmers. However, they can be more easily tempted to sell if it appears that the tourist's reception does not suit them at all.

Investors. Again, some are directly related to the territory. But when their investments concern larger projects (hotels), they may fail and be forced to sell. Others, who come from France or from different European countries, want to try an economic or personal adventure. It happens that the region may not please them as much as they thought, or that their project may not yield as much as they imagined, or see the opportunity to make a big profit, then they finish by selling their property. Of course, they will have to repay a greater or lesser part of the aid, but when the added value is high, it is not an obstacle, although it seems that there have been very few cases.

It is understandable that the investors are the most mobile category and the most tempted by speculative behaviour, while farmers are practically not and newcomers rooted very little. This configuration exists everywhere in France, but with various nuances: the official organisations and the networks can be more or less interested and active, in particular according to the eligibility to the European aids ${ }^{15}$, but it is also possible that there may be very few, and even no interested owners.

Coordination is based on the institutional set-up and a desire for cooperation that deserves further analysis. In the set-up, everything is based on professional networks and intermediaries. Since funding is partly European, it is subject to specific standards that lead to verifications. As a result, people should withdraw, at least partially, from the traditional local relations and political arrangements. This gives a key role to the technicians and more specifically to those who are closest to the local actors, the intermediaries. Professional networks have a great interest in taking as much space as possible and their ability to coordinate and cooperate strengthens them, just like they have an interest in relying on intermediaries.

But in a system of actors so complex and where competition is present, since only a small number of cases benefit from significant aid, conflicts could prevail or play a more important role. If these conflicts aren't present, it is for several reasons, in increasing order of importance:

First, there is a fairly high degree of homogeneity within the network and intermediary experts' community. They know each other, can go from one organism to another and have received trainings of the same nature, generally in the neighbouring city of Toulouse. Above all, there is a strong consensus among them: to continue their activity in the same department and in the same sector.

But the desire for cooperation, when it also reaches the owners, is rooted elsewhere, in the feeling of experiencing a particular adventure at a particular moment and in a very strong identity affirmation. Everyone adheres to a very positive image of the territory. This image is even stronger and widely shared when referred by tourists. At the same time, it is associated with an adventure: that of a kind of rebirth of this territory. As we have seen, although it has always been appreciated and attractive, it has experienced a period of economic difficulties, reflected in the demographic decline. And the idea of rebirth has emerged from two paradigmatic adventures and a fairy tale. On the one hand, a 'star chef' restaurateur in Auch, who for many years was one of the main leaders of his profession and who has developed many initiatives in favour of this territory; on the other, the adventure of a teacher who, in order to save his college which had not enough students, created in 1978 what became one of the major jazz festivals, at least on the scale of France: Jazz in Marciac. The fairy tale is the film of Etienne Chatillez in 1995, Happiness Is in the Meadow, which presents the Gers as a small paradise of traditional rural life and has had immense success. Thus a widely shared collective project is easily built for an economic and social revival of the territory, which naturally goes through heritage.

That means, in order to act on the small heritage with efficiency in a rural context, the coordination between all the actors of planning and local development-not only heritage specialists-is necessary, whether it is complicated as in France or simpler. Such coordination is made possible, or at least easier, by the existence of a community animated by a strong selfesteem and its past. 


\section{A Powerful Legitimacy Structure}

But the self-esteem is based on two things: the image that others have of the self and the legitimacy structures existing at the level of society. In this case, the eyes of visitors have been for a very long time really favourable. Those who came there knew what they were looking for: the good products (Armagnac, foie gras, etc.), the beauty of the landscapes and the architecture, the mild climate and the tranquillity. For decades they have returned a positive perception to local actors, even when they themselves have become inhabitants. But more than that, France has developed a structure of legitimacy of the rural heritage linked to development which presents some originality and which 'frames' the pride and meaning given to the action. To understand it well, a step back is necessary.

As Dominique Poulot (2015) reminds us, in French history, there is first and almost exclusively heritage 'tout court'. The French Revolution is a decisive moment in its constitution. According to Zouain (2003), 'In 1792, the revolutionaries began destroying physical representations of the Old Regime: castles, palaces, private domains, monasteries, churches.' The Convention, which headed the Revolution, became alarmed by the loss of wealth caused by this destruction and decided to protect the 'monuments'.

This has deeply marked the history of heritage in France. It can only be a common good at the level of the Nation. Or it can only carry universal values. However, a new look on the rural landscapes has gradually formed, with the valorisation of the feeling of the nature (Reclus 1866) and the role of the tourist's hikers (Marié 1982).

But the main source of legitimacy for the conception of rural heritage referred to by the actors in our case, at least in the early stages of the heritage process, is an ideological and scientific movement that has not been organised around the concept of heritage. This complex history is primarily that of a scientific discipline: the French rural ethnology, which gathers around a museum institution, also a research laboratory: the National Museum of Popular Arts and Traditions, created in 1937, even linked to the Museum of Man, the main centre of 'exotic' ethnology.

Its first director and central figure is Georges Henri Rivière (1897-1985) who, besides his importance in the scientific world, helped and encouraged the formation of rural museums, which are essentially centred on the technique, objects of everyday life, 'material culture' but generally give little or no room for architecture.

A period of radical transformation of the rural world began in the 1950s. According to Rivière 'it was at this moment that the sheepfolds, barns, stables were emptied' and D. Poulot (2015), who quotes, continues: 'Since then, the loss of use of a large number of buildings has steadily increased, correlatively to the disappearance of farms: hence the challenge of valuing this agricultural building for a decade, which is part of public concerns.'

The European Common Agricultural Policy, set up in 1962, and the accompanying national policies, are radically transforming the countryside. The result is a 'forcedmarket' modernisation of the agricultural economy, which brought prosperity but in no way could avoid the decline in the number of farmers and the uprooting of rural society.

In response to the changes affecting the agricultural world, a sequence, inspired in particular by G-H Rivière, was set up in the 1960s, involving researchers and government actors. It goes through two major CNRS (National Centre for Scientific Research) research operations, one in the early 1960s in the commune of Plozévet ${ }^{16}$ in the most distant Brittany, the other in a mountainous region in central France, the Aubrac. They mark an association between the interest in inherently intangible heritage and the concern for local development, as these two regions were threatened with desertification and that researchers from all disciplines also aimed to find viable solutions for local development. About the research on Aubrac, Rivière says: 'This project marks a very important step in the development of our discipline. It stresses in our field, as do other branches of ethnology at the same time, that our science is not only for the purpose of saving endangered heritage, but that, engaged in the problems of the present, it contributes to a prospective of the man.' (Duclos 2005) ${ }^{17}$ This conception will largely govern the creation of regional parks and eco-museums in the following decade. With the regional parks (created by decree $\mathrm{N}^{\circ} 67-158$ of the $01 / 03 / 1967$ ), 'the objective is to protect from within the most remarkable and most sensitive naturally and culturally homogeneous territories' (Duclos 2005, 143) and the successor of Rivière, Hugues de Varine says, in 1973 about the eco-museum of Creusot: 'The entire community is a living museum whose public is permanently inside. The museum has no visitor, it has inhabitants.' (Duclos 2005, 143) Christian Bromberger (1998, 197-198) summarises the contribution of ethnology: 'to the criteria of history and history of art, defined by experts, ethnology adds those of use, of social consciousness, emotional capital, memory'.

In the end, this source of definition of the rural heritage combines three main characteristics: the interest for an intangible heritage in which it is important to give meaning by associating it with the present, the strong concern for 
local development and the concern for preservation and the valorisation of nature. In other words, the question of endogenous and sustainable economic development, especially agricultural, is inseparable from that of heritage. This association has often been much less obvious in the case of urban heritage.

\section{To Fit in with the Temporalities of the Territory}

Legitimacy is not enough. It is also necessary that the making of heritage falls within the temporalities of the territory to which it applies, which is often not simple. Paradoxically, heritage objects, which come from long time, need to be reinstated in a temporality. Indeed, especially when it comes to a small heritage, its historicity is often forgotten: it has become an object of the present, whether it remains defined by its initial function (a house), or that this function has been erased by its present one (religious building transformed into an agricultural building). A restored and enhanced historic object becomes an object of the present, as a museo-graphic, tourist or simply inscribed in the current daily life: to live a historical house completely restored is to live in the present. While, if the initial characteristics of this house have been respected over time and that adaptations have been made without strong breaks, the historicity of the object is assured. In other words, the most scrupulous restoration with respect to the initial state-or considered as such-is not in itself a re-inscription in the historical time. To restore the value of historicity to an object requires more than that. This problem is particularly sensitive when it concerns objects strongly linked to an economic activity that has changed or disappeared.

This first remark calls for another: the temporalities of the making of heritage process are very different. On the one hand, a slow and incremental temporality: It is characterised by a slow historicisation of the present, with 'stages' during which the stakes of historicity are redefined. In this case the valuation of buildings used by agriculture comes first. The development of the tourist reception policy makes it possible to highlight a series of architectural elements and to improve their inscription in a context which suits them (it is a requirement clearly indicated in the specifications) without creating a strong break with the existing use: the new configuration and use of space is a continuation, even if it brings new elements. It is also what happens with the process of gentrification accomplished by newcomers, whether they own second homes or they settle down completely. This is gentrification in the first sense, defined by Ruth Glass (1964) and very well illustrated, about the transformation of a district of Sydney by Gary Bridge $(2001)^{18}$ : an economic but primarily cultural process to restore their nobility to buildings and recognise the quality of the old environment. The goal is not only to restore a presence to the past in the existing landscape, but also to create a heritage landscape.

On the other hand, there is a 'disruptive' temporality. This is the case, for example, of a massive restoration operation in a city. Aside from the fact that it always creates some social disorganisation, it makes a sudden change of time by starting a new story at the end of the restoration operation: the reference to history breaks with the just preceding time. Festival time is in a way disruptive, in that it creates a temporality that only refers to its own internal logic and is superimposed on the normal rhythm of everyday life. In the same way, the revaluation of an ancient object by contemporary art, as in the case of the water tower presented above is deemed both very effective, as it gives it a lot of value, and very disruptive, as the time 'before', that of its construction or that of its use just before rehabilitation, is completely denied. This is why the third step of the evolution of the studied territory could be considered as disruptive: it is characterised by more important restorations for the hotel industry and by the increase of tourist flows, linked in particular to the festivals and the policy of major sites. It is more productive of 'high places' bringing it closer to the traditional politics of the heritage, centred on the monuments.

The relationship between these two types of temporality is always a problem and in the present case there is reason to fear that the temporality of the last step is in contradiction with that of the first.

Another dimension of temporality is its generational character. A generation of actors, both on the side of the owners (farmers or newcomers) and of technicians or some politicians has lived the heritage as an individual and collective adventure. But this necessarily only lasts for a time: what was an almost militant commitment for one generation becomes a set of opportunities or simply a market for the next. We could show the importance of this phenomenon in the process of making heritage of French historic centres and this is just as true for rural areas. All the more so since, after a while, virtually everything that could become heritage has been covered and, on the other hand, the needs of the tourist economy have been covered.

But the temporality of making heritage is also, in the present case, strongly marked by intangible heritage. 
Indeed, it has been said, the Gers department benefits from many elements of this heritage. Some relate to constructive techniques, and their enhancement in the craft industry is part of the heritage process. But above all, the heritage resources are considerable around gastronomy and food in general. In addition to Armagnac, a product of world renown and of very ancient origin, and foie gras with equivalent characteristics, there are many culinary traditions: all these elements have the advantage of being both in the past (their seniority being part of their value) and in the present (that of the market and tourism); in the tradition, that of the know-how, and in the modernity (that of the gastronomic fashion, the health precautions etc.). The first stage of heritage making is largely based on the promotion of intangible heritage, always associated with the preservation and enhancement of the built heritage, and its producers, who are the owner-farmers. The gentrification performed by newcomers does the same, being more from the point of view of the consumer than the producer. In the third stage, the intangible heritage is no longer an engine, as it is replaced by the event and the 'high place', but it constitutes a necessary context for the quality of the tourist product.

\section{Conclusion}

The above analysis distinguishes three broad dimensions in the rural heritage making.

First, the 'anchored' heritage process. It is represented here by the operations carried out for the farmers. It is then a question of adding value to existing activities, by mobilising or recreating values that are part of a certain temporal continuity with current activities. In this case, the built heritage largely takes its meaning in reference to the intangible heritage, at the same time inscribed in the history and present of local development. This is in line with P-H Rivière's perspective and can be summarised by this statement by F. Choay: 'Local development represents a fundamental anthropological value ... (it is necessary) to move from a static heritage protection, aiming at objects, based on the notion of inventory, with dynamic, structural protection, rooted in everyday life.' (Choay 2006, 222 and 224) 'Gentle' gentrification, carried by secondary residents or new inhabitants strongly attached to the country and the existing heritage is at least partly related to this dimension.

Making heritage as a collective project (the second one) is here represented by the second phase that we have identified. It's not just about adding value to what is there, but creating it as well. In this case, the image of the territory, the narrative that expresses it and the shared development objectives give coherence to the heritage process. Yet they must be shared by many actors that must move in a coordinated manner.

Lastly, 'scenarised' making of heritage tries to increase the value by focusing on a strong attractiveness. This implies giving major importance to high places and events. Heritage is no longer the expression of the community itself; it is a means to create resources that can benefit the territory. It needs specific players, including major tourism operators.

It is clear that the first two dimensions are easily associated and that they are inscribed in the same incremental temporality. The third is necessarily disruptive. The actors of the Gers have tried so far to associate the three-especially because the makers of strong attractors (the festival on one side, Armagnac on the other) are personally deeply rooted. But the fragile equilibrium that seems to have developed can be called into question and, tomorrow, mass tourism can destroy what heritage tourism, rooted or animated by a collective project, has produced.

In any case, one conclusion is necessary: the constitution of the networks that carry the making of heritage is the first essential step. A public policy that does not rely on locally rooted networks does not work well. Decreeing a public policy for the safeguarding and enhancement of heritage without knowing what networks of actors it can rely on is a mistake. And these networks cannot simply gather heritage specialists, they must mobilise diverse and significant local forces. Therefore, any action for rural heritage should start with the formation of these networks and the training of their members. A second requirement is to build the reference narrative, a source of legitimacy at the local level and to inscribe actions in a temporality that is not that of the duration of the projects, but makes sense in relation to local rhythms.

\section{Notes}

1. The term and its definition are borrowed from Merton (1968).

2. One should not, however, downplay the publications that, while having a large share of case studies, clearly aim at the elaboration of middle-range theories, so as the important book directed by Bendix, Eggert, Peselmen (2013) and the report by Gravari-Barbas (2014).

3. On the side of involvement, we can mention the work of Amartya Sen. Coordination is a very important issue in economics, especially in the neo-institutionalist school (with the question of transaction costs), in the 
theories of management and in sociologists of action or organisations.

4. Following Weber (2013) A lot of political science work is also asking this question.

5. Reference is made in particular to grounded theory and the various debates and interpretations to which it has given rise (see Glaser and Straus 2000 [1967]).

6. The system of French local authorities comprises three levels: the Region, the department and the municipality. Until Janurary 1, 2016 metropolitan France (excluding overseas) had 22 regions, 96 departments and more than 34,000 municipalities, often very small and usually grouped in 'communities' that are a kind of federations. The state administration is present at the regional and departmental level.

7. The CAUE (Council of Architecture, Urbanism and Environment) have been created by the law on architecture of January 3, 1977. They aim to promote the quality of architecture, urban planning and of the environment in the departmental territory and are financed by a tax collected by the department. A CAUE is created on the initiative of local officials and chaired by a local elected representative. It is a body of information, advice, awareness and consultation between the actors of planning and urban planning. There are 93 CAUE in France.

8. One of the formulas proposed to the owners involves a small catering service. This activity is free from taxes if the products come from the owner's farm.

9. It is estimated that they carry out half of the current operations.

10. There is also a 'Grands Sites de France' label (attributed to 17 sites currently in 2018, none of which are in the Gers department)

11. Limited to a maximum amount of work or income from the services provided.

12. In general, the funding procedure is as follows: the owner prepares his application files with the tourist networks mentioned above; with the professional who invites the owner to apply; and with the architect. The project is definitively elaborated with specialised organisations: the CAUE (Council of Architecture, Urbanism and the Environment), which will also consult with the State Administration of Heritage for architectural and environmental issues; and with the departmental committee of tourism which oversees the project economical issues. It is then examined by the funding bodies, which, in committee, decide to award or not a subsidy.
13. Mainly: $4^{\text {ème }}$ schéma de destination touristique du Gers (2015-2019) adopté le 30/01/2015. https://www.tourisme-gers.com/gers-tour/2015/actugers/4eme-schematouristique-Gers.pdf

14. Le logement en Midi-Pyrénées- les résidences secondaires. Accessed 29 May 2019. www. Occitanie. developpement-durable.gouv.fr

15. Europe defines the regions it can help from objective statistical analyses of their level of development.

16. One of the most famous French intellectuals and still alive, Edgar Morin, was part of the research team. He wrote a book about this survey (Morin 1967) and invented the notion of 'neo-archaism' to describe the new interest devoted to heritage objects by the most 'modern' part of the population.

17. Quoted by Martine Segalen (2005) who indicates, without more details, that the quotation is extracted from a report addressed to a member of the commission of the CNRS.

18. About rural gentrification see also D. J. Parsons (1980).

\section{References}

Bendix, Regina F. 2008. "Heritage between Economy and Politics: An Assessment from the Perspective of Cultural Anthropology." In Intangible Heritage, edited by Laurajane Smith and Natsuko Akagawa, 253-269. Abington: Routledge.

Bendix Regina F., Aditya Eggert, and Arnika Peselmenn, eds. 2013. Heritage Regimes and the State. Vol. 6 of Göttingen Studies in Cultural Property. Göttingen: Göttingen University Press.

Bridge, Gary. 2001. "Estate Agents as Interpreters of Economic and Cultural Capital: The Gentrification Premium in the Sydney Housing Market." International Journal of Urban and Regional Researsh 25 (1): 87-101.

Bromberger, C. 1998. "Ordinary Monuments of Everyday Life." [Les monuments ordinaires de la vie quotidienne.] In L'abus monumental? [Monumental Abuse?], edited by Debray Régis. Paris: Fayard/Éditions du patrimoine.

Choay, Françoise. 2006. Pour une anthropologie de l'espace [For an Anthropology of Space]. Paris: Seuil.

DATAR. 2003. Quelle France Rurale pour 2020? contribution à une nouvelle politique de développement rural durable [Which Rural France for 2020? Contribution to a New Sustainable Rural Development Policy] La documentation Française. https://www.ladocumentationfrancaise.fr/var/storage/rapports-publics/034000553. pdf 
Duclos, Jean-Claude. 2005. “Depuis Rivière ...” [From River ...] Le Monde alpin et rhodanien. Revue régionale d'ethnologie no. 1-4: 139-150.

Frigolé, Joan. 2010. "Patrimonialization and the Mercantilization of the Authentic. Two Fundamental Strategies in a Tertiary Economy." In Constructing Cultural and Natural Heritage. Parks, Museums and Rural Heritage, edited by Xavier Roigé and Joan Frigolé, 13-24. Catalonia, Spain: Institut Catalá de Recerca en Patrimoni Cultural.

Glaser, Barney, and Anselm Strauss. (1967) 2000. Discovery of Grounded Theory: Strategies for Qualitative Researsch, Reprint, Abington: Routledge.

Glass, Ruth. 1964. London, Aspects of Change. London: McGIbbon \& Kee.

Gravari-Barbas M. 2014. "Synthèse des travaux du consortium PA.TER. MONDI.” [Synthesis of the Work of the Consortium PA.TER MONDI.] Université de Paris 1 Panthéon -Sorbonne.

Groote, Peter. 2005. "World Heritage as NIMBY? The Case of the Dutch Part of the Wadden Sea." In The Politics of World Heritage, Negotiating Tourism and Conservation, edited by David Harrison and Michael Hitchcock, 11-22. Bristol: Channel View Publications.

Heinich, Nathalie. 2009. La fabrique du patrimoine "de la cathédrale à la petite cuillère [The Heritage Factory "from the Cathedral to the Spoon"]. Paris: Éditions de la Maison des sciences de l'homme, Ministère de la Culture.

Marié, Michel. 1982. Un territoire sans nom [An Unnamed Territory]. Paris: Librairie des Méridiens.

Merton, Robert K. 1968. Social Theory and Social Structure. London: Macmillan.

Morin, Edgar. 1967. Commune en France, la métamorphose de Plodémet [Common in France, the Metamorphosis of Plodemet]. Paris: Fayard.

Parsons, D. J. 1980. "Rural Gentrification: The Influence of Rural Settlement Planning Policies." University of Sussex research papers in geography, University of Sussex, Brighton.

Poria, Yaniv, and Gregory Ashworth. 2009. "Heritage Tourism-Current Resource for Conflict.” Annals of Tourism Research 36 (3): 522-525.

Poulot, D. 2015. "You Said 'Rural Heritage"' [Vous avez dit « patrimoine rural ».] Pour no. 226: 39-47.

Reclus, Élisée. 1866. "From the Feeling of Nature in Modern Societies." [Du sentiment de la nature dans les sociétés modernes.] Classiques des sciences sociales, Université du Quebec à Chicoutimi. Accessed 27 May
2019. http://dx.doi.org/doi:10.1522/cla.ree.dus

Segalen, Martine. 2005 "Un regard sur le centre d'ethnologie française. La revue pour l'histoire du CNRS 13-2005." [A Look at the French Ethnology centre. The Review for the History of the CNRS 132005.] Regard surs les laboratoires en sciences humaines et sociales, no. 13. Accessed 2 June 2019. https://journals.openedition.org/histoire-cnrs/1683

Weber, Max. (1922) 2013. Economy and Society. Reprint, Oakland: University of California Press.

Zouain, G. S. 2003. "Cultural Heritage and Economic Theory." A talk given at the University of East-Anglia (Norwich UK) on 12 February 2003.

Zukin, Sharon. 2010. Naked City: The Death and Life of Authentic Urban Places. Oxford: Oxford University. 